\title{
Geographic Variation in Shell Morphology of the Rock Shell, Thais clavigera (Gastropoda: Muricidae) According to Environmental Difference in Korean Coasts
}

\author{
Min Ho Son \\ Korea Inter-University Institute of Ocean Science, Pukyong National University, \\ Busan 608-737, Korea
}

\begin{abstract}
Geographic variation in shell morphology of Thais clavigera (Küster) (Gastropoda: Muricidae) was investigated using samples collected from 24 sites along the Korean coast. Multivariate statistical analysis was applied to 9 morphometric and 4 categorical variables. The shells of $T$. clavigera were classified into two distinct morph types (Type-W and -E). Temperature and salinity of the sampling sites were significantly correlated with the incidence of morph types. Relative abundance of Type-W (thin, yellowish brown shell with triangular nodules) was positively correlated with temperature and negatively correlated with salinity. In contrast, relative abundance of Type-E (thick, dark purple shell with round nodules) was negatively correlated with temperature and positively correlated with salinity. Possible correlation between environmental factors (temperature and salinity) and morphological variations in the shells were discussed.
\end{abstract}

Key words: Morphological variation of shell, Environmental difference, Geographical distribution, Thais clavigera

\section{Introduction}

Thais clavigera (Küster) is a common intertidal carnivorous gastropod found in rocky and boulder shores of the Korean coast. In general, intertidal gastropods display a considerable amount of intraspecific shell variation (De Wolf et al., 1998). In particular, thaisid species, including $T$. clavigera, show great geographical variation in shell morphology (e.g. Nucella lapillus in Moore, 1936; Dicathais species in Phillips et al., 1973; T. emerginata in Kitching, 1976). To understand the processes involved in the maintenance and divergence of species, it is necessary to identify intraspecific patterns of geographic variation (Gianniny and Geary, 1992).

Shell variation of $T$. clavigera has been relatively little studied. Nomura (1926) noted local variation in relative shape (shell width/shell height) from five Japanese populations, but he did not report any trend of geographic distribution of the variants. Local variation of the shell morphology in $T$. clavigera was also studied by Abe (1985) who classified Japanese $T$. clavigera into two forms (Form-C and -P) based on differences in nodule shape and shell color pattern, and suggested that the two distinct forms are probably different species, $T$. clavigera and $T$.

*Corresponding author:mhson@kios.pknu.ac.kr problematica (Baker, 1891). Furthermore, Abe (1994) reported additional evidence that the two forms showed differences in growth rate and prey preference. In Korean waters, pronounced variation in nodule shape of $T$. clavigera has also been noted by Choe and Park (1997) who stated that 'tubercles (=nodules) are highly variable from less developed to rather pointed in shape according to the local population'.

Taxonomy of $T$. clavigera has been controversial so far. This species was originally described as two distinct species, Purpura (=Thais) clavigera (Küster, $1858)$ and $P .(=T$.$) problematica. However, some$ authors (e.g. Tryon, 1880; Pilsbry, 1895) have regarded $T$. problematica as a variant of $T$. clavigera. Although Abe $(1985,1994)$ claimed clear evidence for separating $T$. clavigera into two different species, there was no available data to identify a trend in geographic distribution of these forms in relation to micro- and/or macro-environmental conditions, which may produce ecophenotypic shell variation within a species (Johannesson and Johannesson, 1993).

In order to study this problem further, this work was designed to solve the problem: (1) Is it possible and statistically significant to separate $T$. clavigera into two morph types? (2) Is there any trend in geographic distribution of the possible morph types?, 
and (3) Is there any environmental factor which is significantly correlated with incidence of the morph types? To answer these questions, specimens of $T$. clavigera were collected from 24 sites along the Korean coast, and their shell characters, geographic distributions and environmental conditions of the sites were examined.

\section{Materials and Methods}

Samples of Thais clavigera were collected from intertidal area of 24 exposed rocky and/or rocky and boulder sites along the Korean coast from September 1998 to November 1999 (Table 1, Fig. 1). Approximately 30 shells were collected randomly at each site (Table 1), and immediately fixed in $10 \%$ neutral formalin solution. To delete a possible effect of ontogenetic morphological variation of the shell, sexually immature specimens $(<17 \mathrm{~mm}$ in shell length (SL) in Tong, 1988) were discarded prior to measurement and analysis.

Prior to measuring and scoring shell characters, specimens from each site were examined visually,

Table 1. Sampling sites (RB, rocky shore with some large boulders; $R$, rocky shore) and number of specimens examined at the sites

\begin{tabular}{rll}
\hline Site No. & $\begin{array}{c}\text { Locality } \\
\text { (Substratum condition) }\end{array}$ & $\begin{array}{c}\text { Number of } \\
\text { specimens }\end{array}$ \\
\hline 1 & Kanghwado (RB) & 42 \\
2 & Jackyackdo (RB) & 30 \\
3 & Daebudo (R) & 23 \\
4 & Sunggumi (R) & 30 \\
5 & Taean (RB) & 24 \\
6 & Daecheon (R) & 48 \\
7 & Keyado (R) & 48 \\
8 & Beunsan (R) & 44 \\
9 & Jido (R) & 33 \\
10 & Youngam (R) & 33 \\
11 & Galdu (RB) & 18 \\
12 & Hwaock (R) & 37 \\
13 & Yeousoo (R) & 45 \\
14 & Namhae (R) & 46 \\
15 & Yongchodo (R) & 50 \\
16 & Youngdo (RB) & 24 \\
17 & Haeundae (R) & 36 \\
18 & Yangpo (R) & 38 \\
19 & Pohang (R) & 20 \\
20 & Hupo (RB) & 49 \\
21 & Uljin (R) & 34 \\
22 & Kangnung (R) & 35 \\
23 & Sockcho (R) & 27 \\
24 & Geojin (R) & 24 \\
& & \\
& &
\end{tabular}

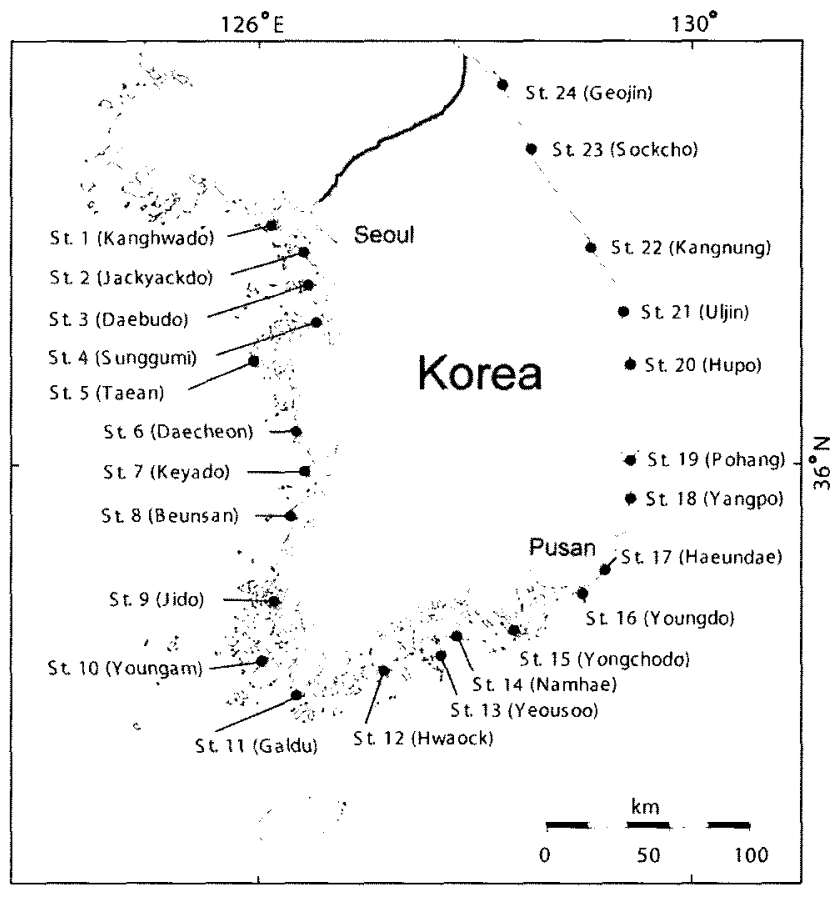

Fig. 1. Sampling sites along the Korean coasts. Samples were collected from exposed intertidal area of the sites.

and tentatively grouped into western ('Type-W') and eastern types ('Type-E') based on 3 distinguishable shell characters (Table 2) that were recognized from preliminary studies. If a specimen had shell characters that usually occurred in the western populations, it was grouped into Type-W and vice versa into Type-E.

Eight linear shell characters (Fig. 2) were measured with vernier calipers to $0.01 \mathrm{~mm}$. Four categorical shell characters were examined and scored (Table 3).

The shell was weighed on an electronic balance to $0.01 \mathrm{~g}$. Prior to weighing the shell, the body was removed with a needle and the shell was boiled in $10 \% \mathrm{KOH}$ solution for $3 \mathrm{~h}$ to remove any remaining tissue. The shell was then washed and cleaned to discard any fouling organisms (e.g. barnacles), and dried in an oven for $2 \mathrm{hrs}$ (ca. $70{ }^{\circ} \mathrm{C}$ ).

Discriminant function analysis (DFA) was applied using MINITAB $\mathrm{PC}^{+}$to evaluate the difference in morphology between shells tentatively grouped into Type-W and -E. The DFA was done using 12 shell characters. Because of the different units of measurement used, raw data were standardized as z-scores to equalize variances and remove scaling effects (Tissot, 1988). Extreme outliers $(\mathrm{n}=16,2 \%)$ were identified using influence statistics (MINITAB: Leverage, 
Table 2. Three distinguishable shell characters used for separation of two morph types tentatively prior to statistical examination

\begin{tabular}{lll}
\hline Character & Western type (Type-W) & Eastern type (Type-E) \\
\hline Colour & Brown or yellowish brown & Purple or grayish dark brown \\
Nodule shape & Sharp and triangular & Round \\
Shell thickness & Thin & Thick \\
\hline
\end{tabular}

Table 3. Four categorical shell characters and scores used in the present study

\begin{tabular}{|c|c|c|c|c|}
\hline \multirow[b]{2}{*}{ Score } & \multicolumn{4}{|c|}{ Shell character } \\
\hline & $\begin{array}{l}\text { Degree of nodule } \\
\text { development }\end{array}$ & $\begin{array}{l}\text { Degree of tooth } \\
\text { development }\end{array}$ & $\begin{array}{l}\text { Condition } \\
\text { of apex }\end{array}$ & Shell color \\
\hline $\begin{array}{l}1 \\
2 \\
3\end{array}$ & $\begin{array}{l}\text { Prominent } \\
\text { Intermediate } \\
\text { Vestigial/not developed }\end{array}$ & $\begin{array}{l}\text { Prominent } \\
\text { Intermediate } \\
\text { Vestigial/not developed }\end{array}$ & $\begin{array}{l}\text { Eroded } \\
\text { Intact }\end{array}$ & $\begin{array}{l}\text { Purple/dark brown } \\
\text { Brown/yellowish brown }\end{array}$ \\
\hline
\end{tabular}

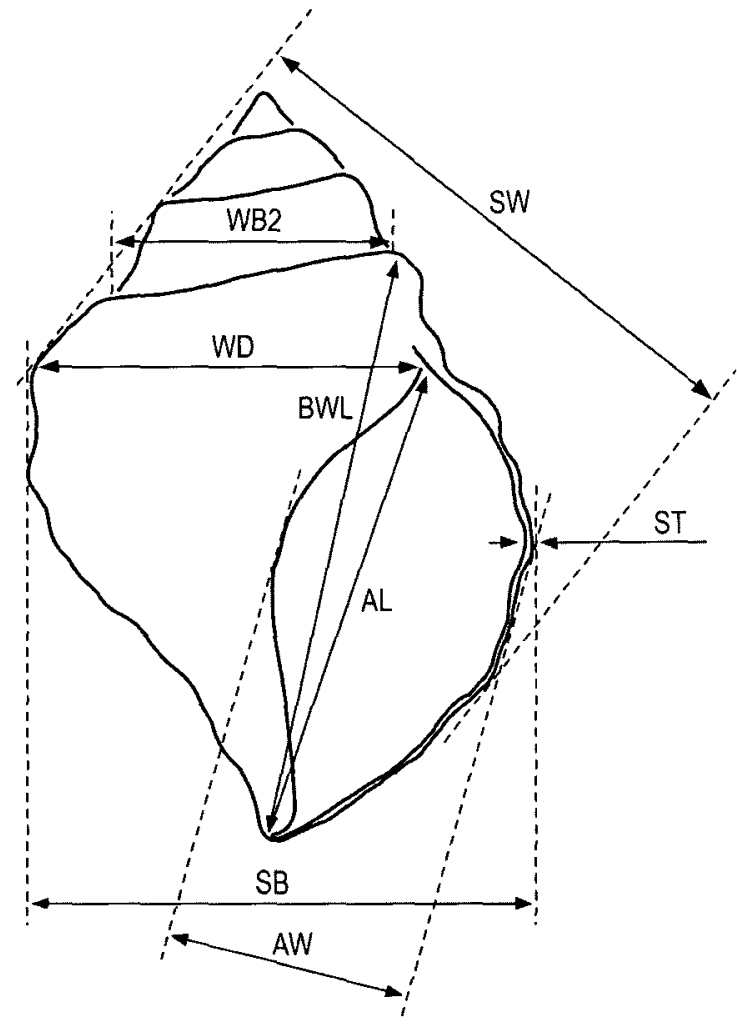

Fig. 2. Eight linear shell measurements used for examination of morphological variation of shells. AL, aperture length; AW, aperture width; BWL, body whorl length; SB, shell breadth; ST, shell thickness; SW, shell width; WD, whorl diameter; WB2, 2nd whorl breadth.

Cook's D and D Fits) and excluded from the analysis. Homogeneity of variances and normal distribution of residuals were confirmed using Hartley's Fmax-test

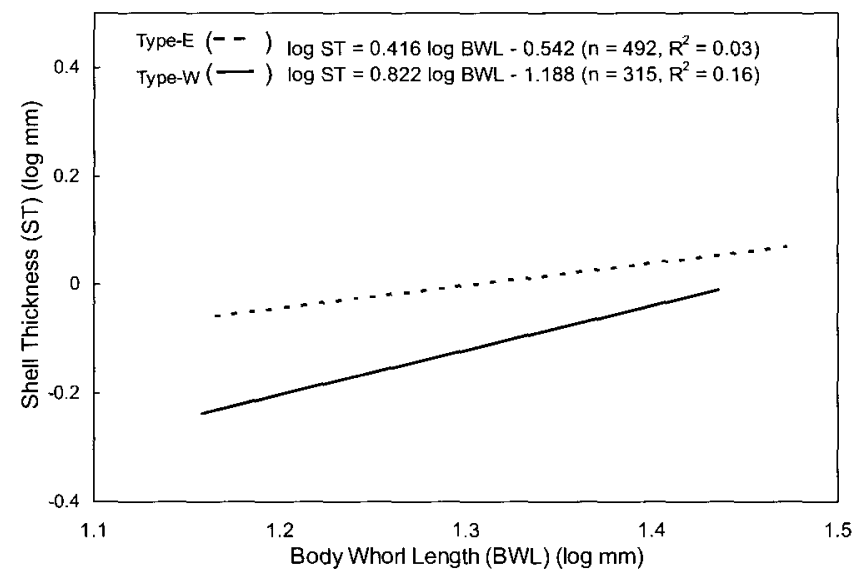

Fig. 3. Relationship between shell thickness (ST) and body whorl length (BWL) for individuals of Type-W and $-E$.

$(\mathrm{P}<0.0001)$ (MINITAB). Analysis included 822 shells from 24 samples.

Of 12 numerical and non-numerical shell characters, shell thickness (ST) was one of the most reliable characters for separation of the two morph types using visual inspection. Shell thickness was subject to log transformation prior to linear regression on body whorl length (BWL, Fig. 2). Difference in the relative ST between two morph types was examined by general factorial analysis of covariance (ANCOVA) of $\log$-transformed values on BWL for shells identified as Type-W and Type-E, with 'type' as the factor and BWL as the covariate, using the SPSS PC'.

For comparison of relative shell size between two morph types, BWL was used as a relative size standard because, in a number of specimens collected from 
eastern and southern sites, apical parts of shells were so eroded that I could not measure shell length accurately. Mean values of BWL of the two morph types were compared using the two-tailed student $t$-test.

External and internal shell morphology of the two morph types were illustrated by drawings made with the aid of a drawing tube. Incidence of each morph type at the sites was represented as percent composition. Mean values of surface seawater temperature and salinity for 30 years at each site were obtained from Hahn et al. (1998). To evaluate any association between environmental factors and percent composition of the morph types, Pearson Correlation Coefficients were calculated using MINITAB.

The Korean coast was divided arbitrary into 3 parts (western coast: St. 1 to 10 , southern coast: St. 11 to 16 , eastern coast: St. 17-24) based on the compass direction to which the coast faces.

\section{Results}

Discriminant function analysis classified into $86.7 \%$ (281/324) in Type-W shell and 91.8\% (457/498) of Type-E (Table 4).

Table 4. Classification of shells by discriminant function analysis (MINITAB), following assignment of shell to the two morphological types on the basis of the visual inspection

\begin{tabular}{lcc}
\hline Morphological type & Type-W & Type- \\
\hline Type-E & 43 & 457 \\
Type-W & 281 & 41 \\
\hline Total number & 324 & 498 \\
Number of correct classification & 281 & 457 \\
\hline \% of correct classification & 86.7 & 91.8 \\
\hline
\end{tabular}

Type-E: thick, heavy and small shell with round nodules; Type- W: thin, light and large shell with spinous nodules

In ST and SWt, slopes of linear regression for Type-W and Type-E significantly differed from zero (ANCOVA; $\mathrm{P}<0.001$ ) for ST/BWL and SWt/BWL. Shells of Type-E were significantly thicker than those of Type-W (ANCOVA; $\mathrm{df}=1,821 ; \mathrm{F}=81.892, \mathrm{P}<$ 0.001 ) (Figure 3) and were significantly heavier than those of the Type-W (ANCOVA; $\mathrm{df}=1,821 ; \mathrm{F}=$ 1594.528; $\mathrm{P}<0.001$ ) (Fig. 4).

Mean shell size (expressed as BWL) of Type-W $(20.9 \pm 42.6)$ was significantly greater than that of

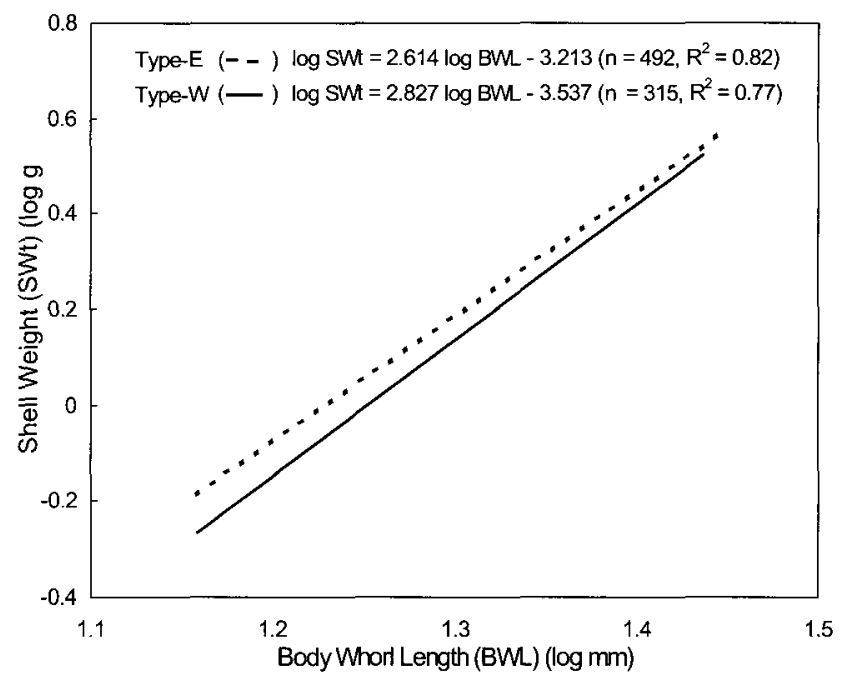

Fig. 4. Relationship between shell weight $(\mathrm{SWt})$ and body whorl length (BWL) for individuals of Type-W and $-E$.

Type-E (19.4 \pm 72.4 ) (two-tailed student t-test, $\mathrm{t}=8.19$, $\mathrm{p}<0.0001$ ). Size frequency distribution of Type- $W$ and Type-E showed normal distribution patterns with different peaks (Fig. 5).

\section{Description of shell morphology}

Type-W (Fig. 6A,B). The shell is thin but robust. The protoconch is usually intact. The teleoconch whorls have highly angular shoulders with conspicuously pointed triangular nodules that are about 11-13 in number on the penultimate and body whorls. The surface is brown or yellowish brown with several dark brown axial bands which run from base to apex. The growth lines are weak, but crowded and relatively sharp spiral cords are present. The body whorl is large and well inflated, and occupies more than three quarters of the shell length. The outer lip is crenulated, corresponding to ribs and interspacial grooves. The inner lip is covered by a pinkish brown callus, which is spread over the columella and umbilicus. The internal wall of the outer lip is yellowish brown with 5-6 pairs of sharp spiral folds that run up to lip margin. Occasionally, the internal wall of the margin is black or dark brown, and has 3-5 tooth-like tubercles (aperture teeth afterward).

Type-E (Fig. 6C, D). The shell is thick and solid with an eroded apex. Frequently, shells are covered in part with several fouling organisms such as bryozoans, barnacles and oyster spat. Most shells have some sign of wear. The teleoconch whorls have round shoulders with round nodules, occasionally 


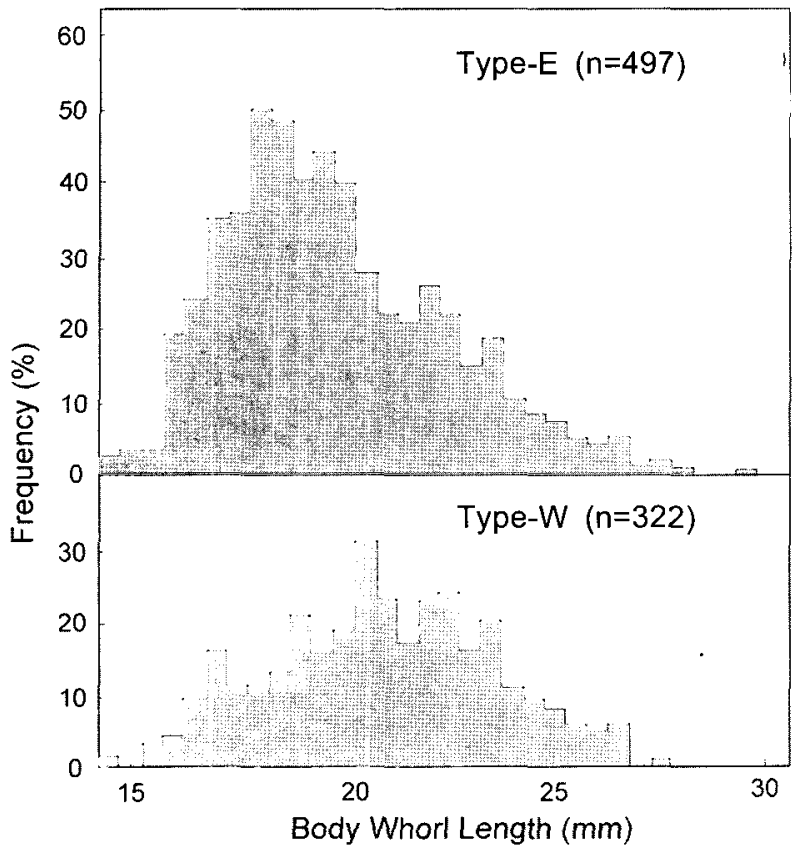

Fig. 5. Size frequency distribution of shells of two morph types.

well-developed, that are about 7-9 in number on the penultimate and body whorls. The surface is dirty-gray or dull, mottled grayish purple with about 6-8 axial bands. The bands usually run from base to apex. Growth lines are weak. Conspicuous 2-4 interstitial white threads run spirally in every row of nodules around the body whorl. The body whorl is moderately inflated and occupies approximately three quarters of the shell length. Usually the apex is severely eroded. The aperture is broadly lunate with a thick outer lip. Occasionally, relatively thin outer lip is crenulated, corresponding to the rounded nodules and interspacial grooves. The inner lip is covered by a yellowish brown callus, which is spread over the columella and umbilicus. The internal wall of the outer lip is yellowish brown. The marginal area of the internal wall is black or dark brown with 3-6 triplets of sharp white spiral folds. Degree of fold development varies from individual to individual. Usually, 3-6 well-developed aperture teeth are present, but occasionally 3-5 rows are seen.

\section{Incidence of the morph types}

Type-W and Type-E occurred mainly in the western (St. 1-10) and eastern coast (St. 17-24), respectively (Fig. 7). In the southern sites (St. 11-16), the two types usually occurred concurrently. Mixed populations were most frequent $(67 \%)$ on the southern coast (Fig. 7). Percent composition of the two morph types showed a clinal change from western coast to eastern coast and vice versa. Along this cline, the composition of the Type-W decreased and that of the Type-E increased, progressively.

\section{Correlation between environmental factors and percent composition of morph type}

Temperature $(r=0.66)$ and salinity $(r=0.72)$ were significantly correlated with percent composition (\%) of morph types (Pearson's correlation coefficient, $\mathrm{p}<0.001$ ) (Figs. 8, 9). Percent composition of Type-W was positively correlated with temperature and negatively with salinity. Type- $W$ occurred mainly at sites where temperature was more than $15^{\circ} \mathrm{C}$ and salinity was less than $34 \%$ (St. 1 to 13 ). In contrast, the
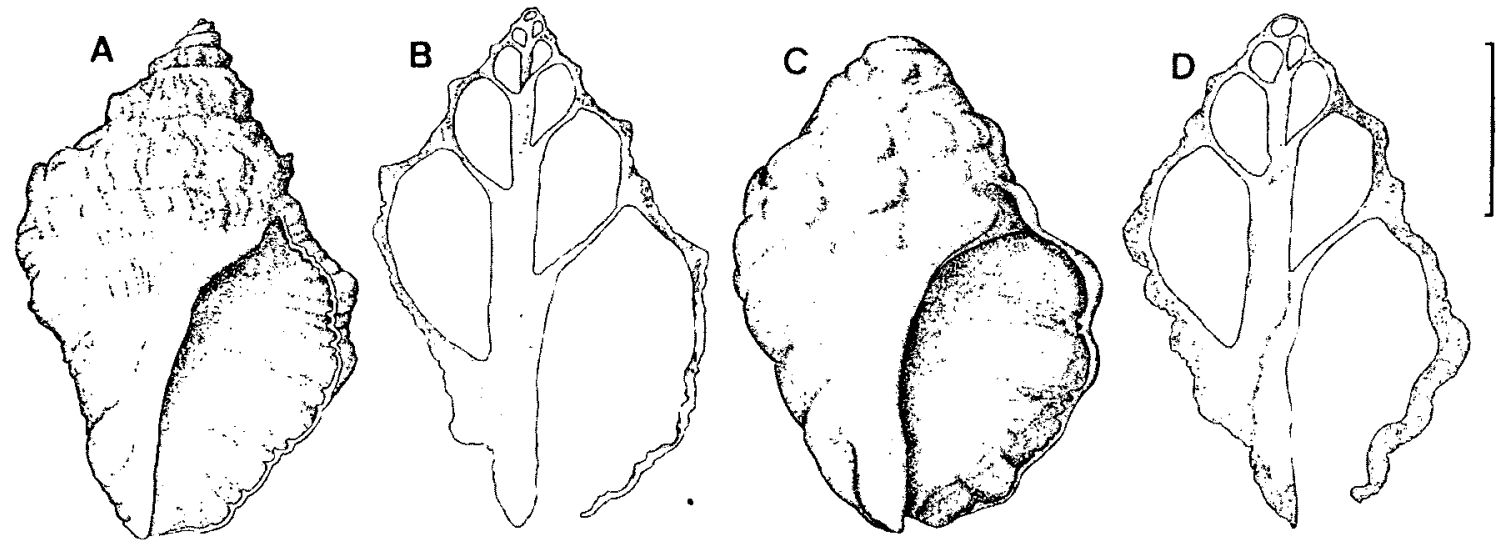

Fig. 6. Thais clavigera. Shells of two morph types. A, apertural view of Type-W; B, longitudinal section of Type-W; C, apertural view of Type-E; D, longitudinal section of Type-E. Scale bar $=1 \mathrm{~cm}$. 


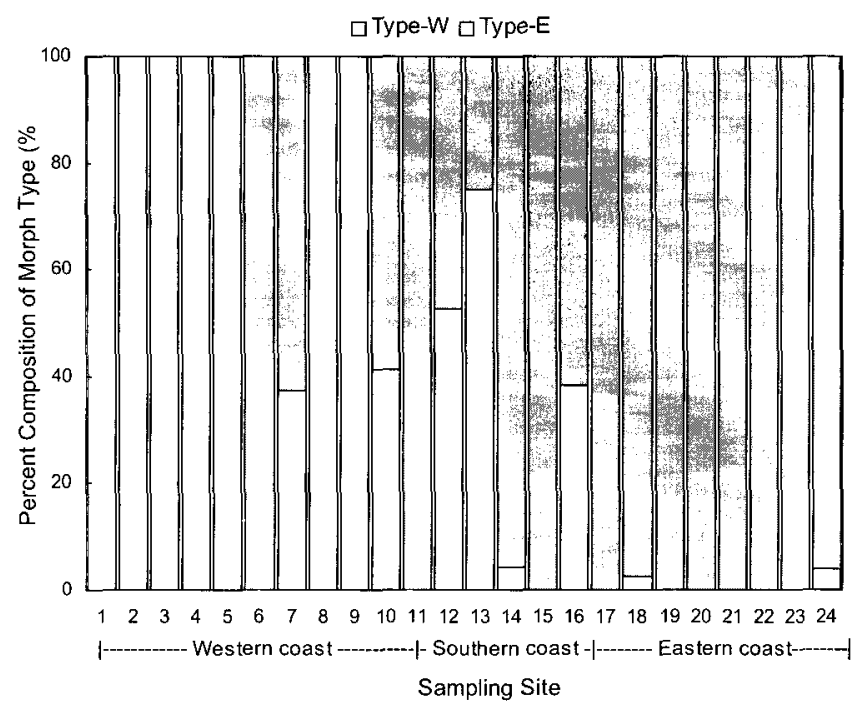

Fig. 7. Percent composition of two morph types (Type-W and -E).

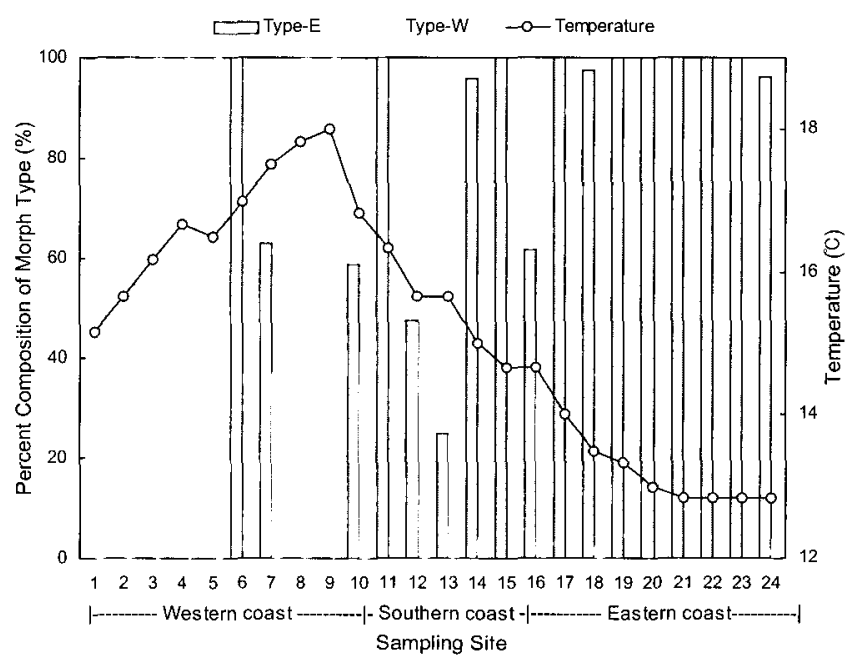

Fig. 8. Relationship between composition of morph types and mean surface temperature.

Type-E occurred mainly at sites where temperature was less than $15^{\circ} \mathrm{C}$ and salinity more than $34 \%$ (St. 14 to 24$)$.

\section{Discussion}

Morphological varients of Thais clavigera might be classified into at least three types or forms because morphology of Type-W in the present study was quite different in most shell characters from the two forms described by Abe (1985). From a macro-geographic point of view, however, Abe's two forms may be

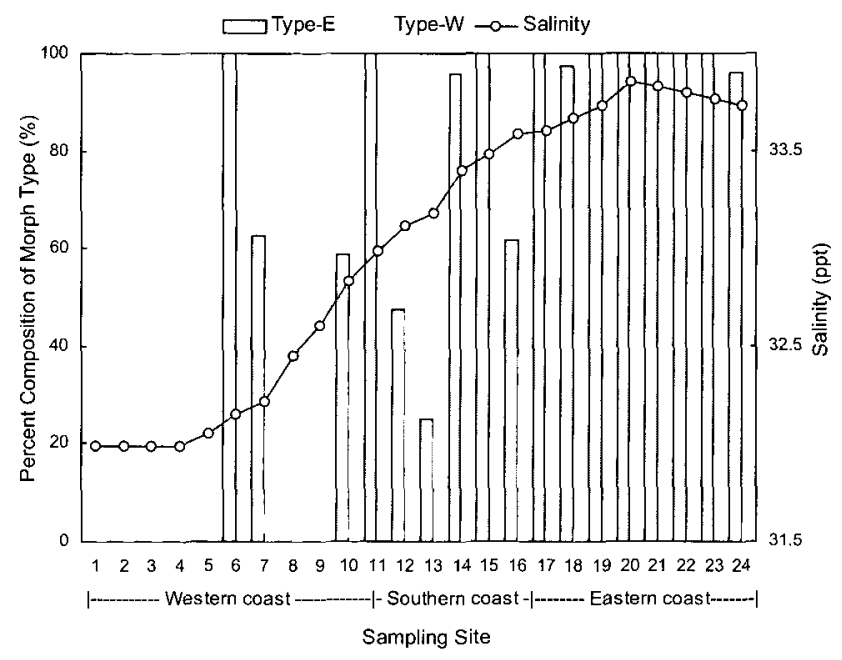

Fig. 9. Relationship between composition of morph types and mean salinity.

categorized into Type-E (thicker, heavier and round shell) of the present study. There is a difference, however, in methodology between Abe (1985) and the present study for identifying morphological variation of the shells: Abe (1985) classified shells into two forms based on only two shell characters (morphometric difference of nodules and shell color patterns), on the other hand, but in this study the shell classified into two types based on overall difference of 12 shell traits by using multivariate statistical analysis (Table 4).

Thinner, lighter and larger shells (Type-W) observed mainly in the western coast except St. 6, on the other hand, thicker, heavier and smaller ones (Type-E) mainly observed in the eastern coast. Occurrence of the habitat-specific types was probably explained as a function of different composition of the two types and ambient temperature and salinity.

Relationship between temperature and calcium metabolism in mollusks is fairly obvious (Wigham, 1975), and many clines, including those of geographic distribution, in mollusks appear to result from the effects of water temperature gradients on shell growth and development (Tissot, 1984). In general, mollusks grow faster with increasing temperature over most of the species-specific temperature range tolerated (Kinne, 1970), and faster growing snails have thinner shells (Bertness, 1984). The present result, thinner and lighter shells predominate in the western coast showing a higher temperature regime $\left(16.7 \pm 0.96{ }^{\circ} \mathrm{C}\right)$ than in the eastern coast $\left(13.3 \pm 0.64^{\circ} \mathrm{C}\right.$ ) (Fig. 8), and, therefore, agree with the observation done by Bertness 
(1984)

Significant difference in salinity between the western $(32.2 \pm 0.30 \%)$ and eastern $(33.7 \pm 0.08 \%)$ coasts (two-tailed student $t$-test: $\mathrm{t}=13.69, \mathrm{p}<0.001$ ) may also produce habitat-specific shell variation of Thais clavigera. Related with salinity, numerous ecophenotypic shell variations of marine gastropods were reported by several workers. Brandwood (1985) noted that reduced salinity acts as an important limit to shell growth in an intertidal species, Littorina rudis, and suggested that this phenomenon is presumably explained by limiting calcium availability in reduced salinity. Tong (1986) found the similar phenomenon with Brandwood (1985) in Hong Kong population of $T$. clavigera. In addition, Newcombe and Kessler (1936) and Remane and Schlieper (1958) reported that reduced salinity can produce thinner shells in bivalve mollusks such as Mya arenaria and Macoma baltica. So far as shell thickness is concerned, the present result agreed with those of the previous studies, although shell thickness is notoriously sensitive to both physical (Kitching et al., 1966) and biological factors (Currey and Hughes, 1982).

Unusual composition of the two morph types was observed in St. 6 (Daecheon) located in the western coast (Figs. 1, 7). All shells of the population were identified as Type-E which was the predominate type along the eastern coast. The shells, which were morphologically characterized by the thickest shell and the shortest aperture length among 24 local populations sampled (Table 1), showed typical shape of Type-E (thicker, heavier and smaller shell). Even though geographic distribution of the present habitatspecific morph types was matched with temperature and salinity clines as a whole, there may be a number of local parameters to produce shell variation of a local population. For instance, abundance of predator (Hughes and Elner, 1979) and food (Kitching and Lockwood, 1974) could be an important factor to produce morphological shell variation in intertidal gastropods. Therefore, the unusual composition in the St. 6 may be explained by the suggestion that there is more important local factor to take the shells shape in Type-E than high-temperature and lowsalinity which are prevailing in the western environment, although the factor remains unknown so far.

Morphological variation of shells of Thais clavigera might be an ecophenotypic response of the shells, in part, to habitat-specific environmental factors, so far as temperature and salinity are concerned, even though role of environment in producing or selecting this variation in the present study remains obscure and no empirical data about causal factor is available. To separate the effects of environmental induction and genetic control, in fact, can be one of the most difficult problems in the analysis of geographic variation, particularly when patterns of variation are correlated with environmental variates (Thorpe, 1976). However, presence of several intermediate shell types (Fig. 10) and a mixture of two morph types in the southern coast may be an additional evidence to support the present interpretation for the morphological shell variation of $T$. clavigera. There was a significant difference in temperature and salinity between the western and eastern coasts of Korea, and the differences may prevent intrusion of planktonic larvae each other between two allopatric types which distribute in the eastern (Type-E) and western (Type-W) coasts separately. However, distribution of temperature and salinity along the Korean coasts showed a gradual decreasing or increasing in all the year round and particularly in reproductive season (April to August; personal observation) (Figs. 11). $T$. clavigera has planktonic stage as veliger larvae for about 2 months after hatching (Nakano and Nagoshi, 1980). If southern coast, showing an intermediate environmental condition between the western and eastern coasts in temperature and salinity, may act a buffer area, planktonic larvae between the allopatric populations can be mixed and dispersed to the opposite area. In addition, Spight (1973) found a similar result in a congeneric species, $T$. lamellosa, that site-specific shapes are phenotypic, since snails with fat and with slender parents all became slender in the laboratory condition. The present results, therefore, could provide additional evidence to support a suggestion, that 'different types of $T$. clavigera is geographic variants of the species', by Pilsbry (1895) and Tong (1986).

Even though there are no empirical data about 'why bryozoans, barnacles and oyster spats prefer the shell of Type-E?'. It is assumed that two possible reasons are related with the preference. The one is mechanical difference of shell surface of the two types. Settling larvae of the foregoing fouling organisms prefer relatively rough shell surface of Type-E to that of Type-W (Fig. 10 B), if rough substrate is more suitable for larval settlement physically than smooth one. The other is chemical difference of shell composition of the two types. If an unidentified specific chemical, consisting the shell of Type-E, attract 


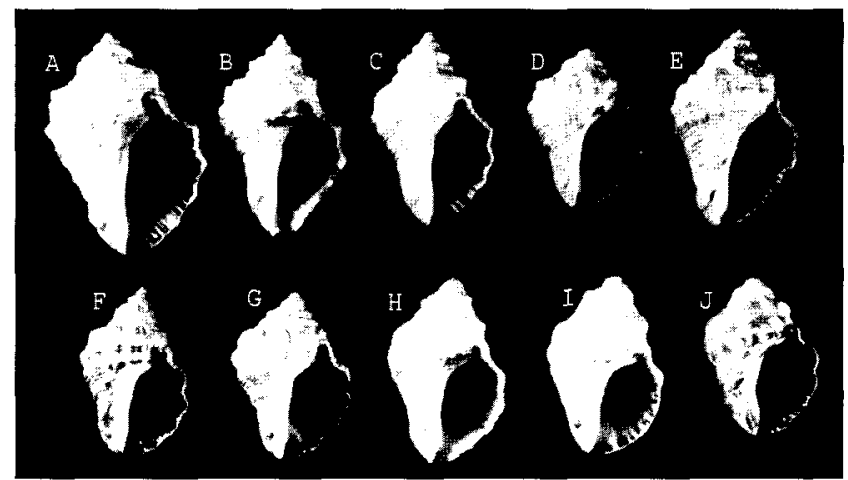

Fig. 10. Typical and intermediate shell types. A, typical form of Type-W; B-I, intermediate forms J, typical form of Type-E.

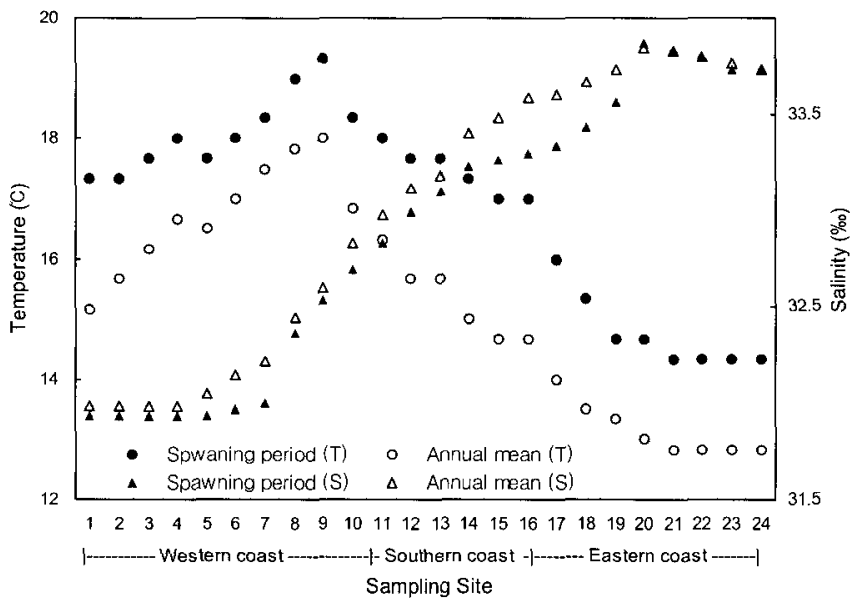

Fig. 11. Comparison of mean surface temperature and salinity between spawning period and annual meanalong the Korean coasts. $\mathrm{T}$, temperature; $\mathrm{S}$, salinity.

settling larvae, the larvae prefer the shells of Type-E to those of Type-W. To accept the foregoing two possible explanations, however, experimental examination might be needed for difference of settlement incidence of the larvae between two substrate types (the shell of Type-E and $-W$ ).

Despite the limitation of the present study, it is concluded tentatively that, in $T$. clavigera, the larger and thinner shells with spinous nodules predominate in low-salinity and high-temperature area and the smaller and thicker shells with round nodules predominate in high-salinity and low-temperature area, and these two different types are variants of one species, $T$. clavigera. Thus, the present findings revealed that an additional evidence that phenotypes of the gastropod shell is molded by their surrounding physical environment, such as temperature and salinity, and that Korean $T$. clavigera can be categorized into two groups (Type-E and $-W$ ) by temperature and salinity regimes.

\section{References}

Abe, N. 1985. Two forms of Thais clavigera (Küster, 1858). Venus (Jap. J. Malacol.), 44, 15-26.

Abe, N. 1994. Growth and prey preference of the two forms in Thais clavigera (Küster) under rearing. Venus (Jap. J. Malacol.), 53, 113-118.

Baker, F.C. 1891. Descriptions of new species of Muricidae, with remarks on the apics of certain forms. Proc. Rochseter Aca. Sci., 1, 129-137.

Bertness, M.D. 1984. Habitat and community modification by an introduced herbivorous snail. Ecology, 65, 370-381.

Brandwood, A. 1985. The effects of environment upon shell construction and strength in the rough periwinkle Littorina rudis Maton (Mollusca: Gastropoda). J. Zool., London, 206, 551-565.

Choe, B.L. and J.K. Park. 1997. Description of muricid species (Gastropoda: Neogastropoda) collected from the coastal areas of South Korea. Kor. J. Biol. Sci., 1, 281-296.

Currey, J.D. and R.N. Hughes. 1982. Strength of the dogwhelk Nucella lapillus and the winkle Littorina littorea from different habitats. J. Ani. Ecol., 51, 47-56.

De Wolf, H., T. Backeljau and S. Van Dongen. 1998. Largescale patterns of shell variation in Littorina striata, a planktonic developing periwinkle from Micronesia (Mollusca: Prosobranchia). Mar. Biol., 131, 309-317.

Gianniny, G.L. and D.H. Geary. 1992. Geographic and temporal variation in shell morphology of Acanthina species from California and northern Baja California. The Veliger, 35, 195-204.

Hahn, S.D., Y.S. Kang, H.D. Jeong, H.G. Jin, C.M. Kang, Y.S. Suh, H.J. Oh, J. H. Park and L. H. Jang. 1998. Climatic Atlas of TS and DO in Korean Waters (1966-1995). Nat'l. Fish. Res. Dev. Inst., Pusan, 212 pp.

Hughes, R.N. and R.W. Elner. 1979. Tactics of a predator, Carcinus maenas, and morphological responses of the prey, Nucella lapillus. J. Ani. Ecol., 48, 65-78.

Johannesson, K. and B. Johannesson. 1993. Morphological differentiation and genetic cohesiveness over a microenvironmental gradient in the marine snail Littorina saxatilis. Evolution, 47, 1770-1787.

Kinne, O. 1970. Temperature. In: Marine Ecology, Vol. 1, Kinne, O. ed. Wiley Interscience, John Wiley and Sons Ltd., New York, pp. 407-514.

Kitching, J.A. 1976. Distribution and changes in shell form of Thais spp. (Gastropoda) near Bamfield, B.C. J. Exp. Mar. Biol. Ecol., 23, 109-126.

Kitching, J.A. and J. Lockwood. 1974. Observations on 
shell form and its ecological significance in thaisid gastropods of the genus Lepsiella in New Zealand. Mar. Biol., 28, 131-144.

Kitching, J.A., L. Muntz and F.J. Ebling. 1966. The ecology of Lough Ine. XV. The ecological significance of shell and body forms in Nucella. J. Ani. Ecol., 35, 113-126.

Kster, H.C. 1858. Die gattungen Buccinum, Purpura, Concholepas und Monoceras. In: Systematisches Conchylien-cabinet Von Martini und Chemnitz. Kobelt, W. and Kster, H.C. eds. Bauer and Raspe: Nuremberg, pp. 1-229. (in German)

Moore, H.B., 1936. The biology of Purpura lapillus L. shell variation in relation to environment. J. Mar. Biol. Ass., UK, 21, 61-89.

Nakano, D. and M. Nagoshi. 1980. Growth and age of Thais clavigera (Küster), prosobranchia, in tidal zone around Shima Peninsula, Japan. 25th Anni. Mem., J. Toba Aquar., $92 \mathrm{pp}$.

Newcombe, C.L. and H. Kessler. 1936. Variation in growth indices of Mya arenaria $\mathrm{L}$. on the Atlantic coast of North America. Ecology, 17, 429-443.

Nomura, E. 1926. On the local variation in some littoral gastropods. Sci. Rep. Tohoku Univ., Biol., 2, 249-253.

Phillips, B.F., B.R. Campbell and B.R. Wilson. 1973. A multivariate study of geographic variation in the whelk Dicathais. J. Exp. Mar. Biol. Ecol., 11, 27-69.

Pilsbry, H.A. 1895. Catalogue of the Marine Mollusks of Japan. Detroit, $103 \mathrm{pp}$.

Remane, A. and C. Schlieper. 1958. Die Biologie des Brackwassers, Schweizerbart, Stuttgart. Binnengewsser, $63 \mathrm{pp}$. (in Germany)

Spight, T.M. 1973. Ontogeny, environment, and shape of a marine snail Thais lamellosa Gmelin. J. Exp. Mar. Biol. Ecol., 13, 215-228.

Thorpe, R.S. 1976. Biometric analysis of geographic variation and racial affinities. Biol. Rev., 51, 407-452.

Tissot, B.N. 1988. Geographic variation and heterochrony in two species of cowries (Genus Cypraea). Evolution, 42, 103-117.

Tong, K.Y. 1986. The population dynamics and growth of Thais clavigera and Morula musiva (Gastropoda: Muricidae) in Hong Kong. Asian Mar. Biol., 3, 145162.

Tong, K.Y. 1988. The reproductive biology of Thais clavigera and Morula musiva (Gastropoda: Muricidae) in Hong Kong. Asian Mar. Biol., 5, 65-75.

Tryon, G.W. 1880. Manual of Conchology: Muricinae, Purpurinae. Academy of Natural Sciences, Philadelphia, $82 \mathrm{pp}$.

Wigham, G.D. 1975. Environmental influences upon the expression of shell form in Rissoa parva (Da Costa) (Gastropoda: Prosobranchia). J. Mar. Biol. Ass., UK, $55,425-438$.

(Received November 2003, Accepted December 2003) 